\title{
CYWILNOPRAWNY MODEL OCHRONY TAJEMNICY PRZEDSIĘBIORSTWA PRZEWOZOWEGO
}

\author{
WPROWADZENIE
}

W ostatnich latach branża transportowa notuje stały wzrost przewożonych ładunków. Według danych Głównego Urzędu Statystycznego w 2018 r. wykonano o 6,8\% więcej przewozów towarów (liczonych w tonach przewiezionych towarów) w stosunku do roku poprzedzającego ${ }^{1}$. Statystyka ta dotyczy wszystkich rodzajów transportu, natomiast w odniesieniu do poszczególnych jego gałęzi na szczególną uwagę zasługuje wzrost liczby towarów przewiezionych samochodami. W stosunku do 2017 r. zanotowano wzrost o 7,2\%, natomiast w stosunku do 2016 r. - aż o 21,1\%². To sprawia, że ta gałąź gospodarki cieszy się niesłabnącym zainteresowaniem przedsiębiorców w zakresie prowadzenia działalności gospodarczej w tym sektorze. Spośród wszystkich rodzajów transportu można zauważyć w praktyce tendencję do powstawania z roku na rok coraz większej liczby przedsiębiorstw trudniących się transportem samochodowym towarów. Aby zobrazować tę tendencję można wskazać, że obecnie w samej Centralnej Ewidencji i Informacji o Działalności Gospodarczej widnieje aż 378812 przedsiębiorców, którzy wskazali transport drogowy towarów (kod PKD 49.41.Z) jako przedmiot ich działalności, a nie należy zapominać, że znaczna liczba przedsiębiorców zarejestrowanych w rejestrze przedsiębiorców Krajowego Rejestru Sądowego w formie spółek prawa handlowego para się tą działalnością. Wiąże się to zapewne z relatywnie najniższym kapitałem,

Mgr Michą Wojdala - asystent w Instytucie Nauk Prawnych, Wydział Prawa i Administracji, Uniwersytet Szczeciński, ul. Narutowicza 17a, 70-240 Szczecin; m.wojdala@gmail.com; https:// orcid.org/0000-0002-5156-3140

${ }^{1}$ Dane za informacjami sygnalnymi GUS z dnia 14 czerwca 2019 r., https://stat.gov.pl/download/ gfx/portalinformacyjny/p1/defaultaktualnosci/5511/11/7/1/przewozy_ladunkow_i_pasazerow_w_2018_ roku.pdf [dostęp: 18.07.2019].

2 Tamże. 
jaki należy zainwestować w tego typu działalność oraz najmniej uciążliwą drogą do uzyskania stosownych zezwoleń na jej prowadzenie. Z powyższych względów przedmiotem niniejszych rozważań będzie specyfika tajemnicy przedsiębiorstw przewozowych działających w obszarze transportu samochodowego towarów. Co prawda znaczna część postawionych tez i wniosków będzie dotyczyć również innych gałęzi transportu, niemniej punktem wyjścia pozostaje transport samochodowy.

Ponadto niniejsze rozważania będą obejmować swoim zakresem również przedsiębiorców zajmujących się spedycją w powszechnym rozumieniu tego terminu. Wynika to z faktu, że w języku potocznym przez „spedycję” rozumie się organizację przewozu towarów, natomiast w praktyce nadzwyczaj często między nadawcą przesyłki a „spedytorem” dochodzi do zawarcia umowy przewozu, w której osoba organizująca przewóz odpowiada wobec nadawcy (i ewentualnie odbiorcy) jak przewoźnik, który posługuje się podwykonawcą, tj. dalszym przewoźnikiem. Wiąże się to zazwyczaj z tym, że wielu przedsiębiorców przewozowych dysponuje własną flotą transportową $\mathrm{i}$ ich działalność ma charakter mieszany - z jednej strony przedsiębiorcy ci wykonują transport we własnym zakresie, a częściowo zlecają wykonanie niektórych umów podwykonawcom, jednakże nie zmienia to charakteru zawartej z nadawcą umowy oraz ich odpowiedzialności. Dla działalności tych przedsiębiorców podstawowe znaczenie ma art. 5 ust. 1 ustawy o transporcie drogowym $^{3}$, który stanowi, że podjęcie i wykonywanie transportu drogowego, z zastrzeżeniem art. 5b ust. 1 i 2, wymaga uzyskania zezwolenia na wykonywanie zawodu przewoźnika drogowego. $Z$ kolei art. $5 \mathrm{~b}$ ust. 2 tej ustawy stanowi, że podjęcie i wykonywanie transportu drogowego w zakresie pośrednictwa przy przewozie rzeczy wymaga uzyskania odpowiedniej licencji. Co prawda ustawodawca nie podjął się zdefiniowania pośrednictwa przy przewozie rzeczy, jednakże definicja ta wydaje się zbędna wobec oczywistego brzmienia przepisów, z których jednoznacznie wynika, że licencja w zakresie pośrednictwa przy przewozie rzeczy nie uprawnia do wykonywania transportów własnymi środkami, a jedynie do pośredniczenia przy organizacji przewozów, a zatem - do prowadzenia działalności $\mathrm{w}$ zakresie spedycji $\mathrm{w}$ powszechnym rozumieniu tego terminu. $\mathrm{Z}$ kolei podmiot posiadający zezwolenie na wykonywanie zawodu przewoźnika drogowego z mocy przepisów powszechnie obowiązującego prawa (w szczególności - art. 5 Prawa przewozowego ${ }^{4}$, który stanowi, że przewoźnik może powierzać wykonanie przewozu innym przewoźnikom na całej przestrzeni przewozu lub jej części, jednakże ponosi odpowiedzialność za ich czynności jak za swoje własne) może prowadzić działalność w zakresie powszechnie rozumianej spedycji.

\footnotetext{
${ }^{3}$ Ustawa z dnia 6 września 2001 r. o transporcie drogowym, Dz. U. z 2019 r., poz. 58 z późn. zm.

${ }^{4}$ Ustawa z dnia 15 listopada 1984 r. - Prawo przewozowe, Dz. U. z 2017 r., poz. 1983 z późn. zm.
} 
Reasumując, za przedsiębiorcę przewozowego (w zakresie transportu samochodowego) należy uznać zarówno przewoźników drogowych, realizujących transport własnymi środkami transportu, jak i spedytorów, organizujących przewozy. Obie te grupy podmiotów funkcjonują na rynku na podobnych zasadach i tajemnice ich przedsiębiorstw cechują zbliżone elementy, a naruszenie tej tajemnicy może wywołać podobne skutki.

Z uwagi na fakt, że tematyka niniejszych rozważań obejmuje cywilnoprawny model ochrony tajemnicy przedsiębiorstwa, spod ich zakresu wyłączona zostanie analiza przepisów karnych ustawy o zwalczaniu nieuczciwej konkurencji ${ }^{5}$ ze względu na ich odmienny charakter.

\section{ISTOTA TAJEMNICY PRZEDSIĘBIORSTWA PRZEWOZOWEGO}

\subsection{ISTOTA TAJEMNICY PRZEDSIĘBIORSTWA W OGÓLNOŚCI}

Aby spróbować zdefiniować tajemnicę przedsiębiorstwa przewozowego, należy w pierwszej kolejności dokonać charakterystyki definicji tajemnicy przedsiębiorstwa jako takiej. Ustawodawca w art. 11 ust. 2 ustawy o zwalczaniu nieuczciwej konkurencji definiuje ją jako informacje techniczne, technologiczne, organizacyjne przedsiębiorstwa lub inne informacje posiadające wartość gospodarczą, które jako całość lub w szczególnym zestawieniu i zbiorze ich elementów nie są powszechnie znane osobom zwykle zajmującym się tym rodzajem informacji albo nie są łatwo dostępne dla takich osób, o ile uprawniony do korzystania z informacji lub rozporządzania nimi podjął, przy zachowaniu należytej staranności, działania w celu utrzymania ich w poufności. Widoczne są tu trzy elementy istotne dla uznania danego zbioru informacji za tajemnicę przedsiębiorstwa. Informacje te:

1) muszą posiadać wartość gospodarczą,

2) nie są powszechnie znane dla osób zajmujących się tym rodzajem informacji oraz

3) osoba uprawniona do korzystania $z$ nich podjęła działania w celu utrzymania ich $\mathrm{w}$ poufności.

Wartość gospodarcza informacji koresponduje z potocznym pojęciem terminu know-how, które oznacza obecnie zdolność, wiedzę, umiejętność w zakresie osią-

\footnotetext{
${ }^{5}$ Ustawa z dnia 16 kwietnia 1993 r. o zwalczaniu nieuczciwej konkurencji, Dz. U. z 2019 r., poz. 1010.
} 
gania określonego rezultatu lub prowadzenia działalności ${ }^{6}$. Wprawdzie w doktrynie trafnie zauważa się, że „,W polskim języku prawniczym przez długie lata pojęcie know-how oznaczało w zasadzie tajemnice o charakterze technicznym i technologicznym, których przedmiotem były zachowane w poufności wynalazki i projekty racjonalizatorskie, jednak jednocześnie wskazywano na ich znaczenie gospodarcze, przyjmując z czasem, że pojęcie know-how obejmuje doświadczenia o charakterze technicznym i techniczno-organizacyjnym oraz doświadczenia o charakterze finansowym i handlowym przydatne do prowadzenia przedsiębiorstwa, które nie są związane z cyklem produkcyjnym" "7. Można zatem uznać, że chodzi o informacje, które ogólnie są przydatne dla prowadzenia określonego rodzaju działalności, pozwalające osiągnąć jak najlepsze rezultaty.

Druga przesłanka umożliwiająca uznanie danych informacji za tajemnicę przedsiębiorstwa, tj. brak powszechności tych informacji wprowadza pewne ograniczenie zbioru informacji. Nie ulega bowiem wątpliwości, że wiedza powszechnie znana w danej dziedzinie tajemnicą nie jest. Nie oznacza to jednak, że dostęp do informacji musi być ograniczony jedynie do osoby przedsiębiorcy, aby uznać je za tajemnicę. Jak słusznie stwierdził P. Bogdalski, sposób definiowania tajemnicy przesądza o tym, iż treść danych nią objętych może być znana nie tylko jednej osobie, lecz również określonej grupie osób ${ }^{8}$. Podobne stanowisko wyraził S. Sołtysiński, który stwierdził, że tajemnica nie traci bowiem swego charakteru, gdy wie o niej ograniczone grono osób zobowiązanych do dyskrecji, w tym kontrahenci przedsiębiorcy ${ }^{9}$. Oznacza to, że jeżeli dany zbiór informacji przydatnych do prowadzenia określonej działalności i osiągania danych rezultatów jest znany szerszej grupie ludzi (np. pracowników zatrudnionych na danym stanowisku), nadal może być postrzegany jako tajemnica przedsiębiorstwa.

Co więcej, informacje te mogą być, teoretycznie, rozproszone między poszczególnych pracowników w ten sposób, aby jako uporządkowana całość stanowić informacje przydatne gospodarczo, stanowiące tajemnicę przedsiębiorstwa oraz aby w oderwaniu od pozostałych danych składających się na tę całość nie mogły stać się informacją przydatną. Przekładając ten przykład na grunt przedsiębior-

${ }^{6}$ S. SoŁtysiński, Komentarz do art. ... ustawy o ..., [w:] System Prawa Własności Intelektualnej, t. III: Prawo wynalazcze, red. J. Szwaja, A. Szajkowski, Wrocław: Wydawnictwo Ossolineum 1990, s. 63.

${ }^{7}$ E. Nowińska, Komentarz do art. ..., [w:] E. Nowińska, K. SzczepanowsKa-KozŁowsKa, Ustawa o zwalczaniu nieuczciwej konkurencji. Komentarz, LEX/el. 2017.

${ }^{8}$ P. BogdalSKI, Tajemnica przedsiębiorstwa - zagadnienia konstrukcyjne, „Monitor Prawniczy” 6 (1997), s. 228.

${ }^{9}$ S. SoŁtysiński, S. Gogulski, Komentarz do art. ..., [w:] Ustawa o zwalczaniu nieuczciwej konkurencji. Komentarz, red. J. Szwaja, Warszawa: Wydawnictwo C.H. Beck 2016, s. 421. 
ców przewozowych można nakreślić sytuację, w której jedna grupa pracowników odpowiada za trasy przewozów (tj. miejsca załadunków i rozładunków), inna za stawki wynagrodzenia uzyskiwane od kontrahentów za wykonany przewóz, a jeszcze inna - za stawki proponowane podwykonawcom (o ile, rzecz jasna, przedsiębiorca się nimi posługuje). Takie rozproszenie informacji mogłoby być rozpatrywane w kontekście trzeciej przesłanki, tj. podjęcia działań w celu ochrony danych informacji. Na pierwszy rzut oka wydaje się, że odpowiednie ukształtowanie struktury organizacyjnej przedsiębiorstwa pozwoliłoby dokonać takiego rozproszenia i sprawić, aby dana część informacji (np. wyłącznie o wysokości wynagrodzeń za wykonane umowy) w oderwaniu od pozostałych informacji nie była przydatna dla konkurencji. Jednak w praktyce byłoby to raczej niemożliwe, szczególnie w przypadku przedsiębiorców zajmujących się spedycją w powszechnym rozumieniu. Informacje o wynagrodzeniu uzyskanym od zleceniodawcy oraz o wynagrodzeniu podwykonawcy muszą pozostać w posiadaniu jednej osoby, aby wypracować zysk. Nie ulega bowiem wątpliwości, że aby przedsięwzięcie było opłacalne, wynagrodzenie proponowane przewoźnikowi musi być odpowiednio niższe od wynagrodzenia otrzymanego od zleceniodawcy - odwrotna sytuacja prowadziłaby do straty. Podobnie sprawa ma się w odniesieniu do obsługiwanych tras, bowiem zwykle od ich długości zależy wysokość wynagrodzenia przedsiębiorcy (zwykle im trasa jest dłuższa, tym wynagrodzenie jest wyższe, ale jednocześnie stawka za jeden kilometr trasy się zmniejsza). Stąd też komplet wskazanych wyżej danych w praktyce znajduje się w posiadaniu danej osoby (spedytora), który planuje daną trasę, przyjmując od zleceniodawcy umowę przewozu do wykonania, tj. otrzymuje dane o miejscu załadunku i rozładunku, negocjuje stawkę wynagrodzenia oraz poszukuje podwykonawcy, który wykona umowę jak najniższym kosztem, co z kolei maksymalizuje zysk.

Jak zatem powinna wyglądać ochrona informacji podjęta przez przedsiębiorcę, aby uznać je za tajemnicę przedsiębiorstwa? Przede wszystkim musi podjąć jakiekolwiek działania zmierzające do zachowania w poufności określonych informacji. Jak trafnie stwierdził Sąd Najwyższy, „na przedsiębiorcy spoczywa dodatkowy ciężar podjęcia odpowiednich działań organizacyjnych i porządkowych w celu utrzymania danej wiadomości w tajemnicy. Powinien on ponadto poinformować pracownika o poufnym charakterze wiedzy, techniki, urządzenia itp." ${ }^{.10}$. Na gruncie stanu faktycznego, będącego przedmiotem rozstrzygnięcia sądu, skład orzekający doszedł do wniosku, że wykorzystanie przez pracownika we własnej działalności gospodarczej informacji, co do których przedsiębiorca (pracodawca) nie podjął

${ }^{10}$ Zob. uzasadnienie wyroku Sądu Najwyższego z dnia 3 października 2000 r., sygn. akt I CKN 304/00, „Orzecznictwo Sądu Najwyższego Izba Cywilna” 2001, nr 4, poz. 59. 
niezbędnych działań w celu zachowania ich poufności, należy traktować jako wykorzystanie powszechnej wiedzy, do której przedsiębiorca nie ma żadnych ustawowych uprawnieńn ${ }^{11}$. Wprawdzie SN podkreślił, że jest to wiedza specjalistyczna, która niekoniecznie musi być szeroko znana nawet $\mathrm{w}$ obrębie danej działalności, jednakże fakt niepodjęcia przez przedsiębiorcę żadnych środków mających zachować w poufności określone informacje skutkuje niemożnością uznania ich za jego tajemnicę, która podlegałaby ochronie prawnej. W praktyce najczęściej stosowanymi środkami tego typu są klauzule poufności określonych informacji, zawarte w umowie o pracę czy również umowy o zakazie konkurencji po ustaniu stosunku pracy.

W kontekście podjęcia przez przedsiębiorcę działań, czy raczej - przejawienia woli, aby dana informacja stanowiła tajemnicę przedsiębiorstwa ,można również zwrócić uwagę na stanowisko Naczelnego Sądu Administracyjnego w Warszawie, który doszedł do wniosku, że ,interpretacja [(art. 61 Konstytucji RP, art. 1 ust. 1 oraz art. 2 ust. 1 i 2 ustawy o dostępie do informacji publicznej $\left.{ }^{12}\right)$ ] dopuszczająca możliwość objęcia tajemnicą przedsiębiorstwa informacji publicznej na podstawie arbitralnej decyzji przedsiębiorcy musi być uznana za wadliwą. Przyjęcie takiego stanowiska czyniłoby bowiem fikcyjnym konstytucyjnie chronione prawo obywatela do uzyskania informacji publicznej, ponieważ dla pozbawienia go dostępu do szerokiego kręgu informacji wystarczające byłoby formalne i niepodlegające jakiejkolwiek kontroli zadeklarowanie przez przedsiębiorcę zastrzeżenie, że określone informacje stanowią tajemnicę przedsiębiorstwa"13. Należy przy tym pamiętać, że wyrok ten zapadł na tle wykładni przepisów ustawy o dostępie do informacji publicznej, a zatem informacji szczególnej kategorii, dlatego też wyjątek ten należy uznać za trafny.

\subsection{TAJEMNICA PRZEDSIĘBIORSTWA PRZEWOZOWEGO}

Mając na uwadze powyższe rozważania należy dojść do wniosku, że tajemnicą przedsiębiorstwa przewozowego będą wszelkie informacje służące osiąganiu zysku przez przedsiębiorcę przewozowego, a które nie są znane konkurentom i co do których przedsiębiorca podjął działania, aby zachować je w poufności. Katalog ten jest, rzecz jasna, katalogiem otwartym, jednak można wyróżnić podstawowe informacje o tym charakterze. Zaliczyć do nich można w szczególności:

\footnotetext{
${ }^{11}$ Tamże.

${ }^{12}$ Ustawa z dnia 6 września 2001 r. o dostępie do informacji publicznej, Dz. U. z 2019 r., poz. 1429.

${ }^{13}$ Wyrok Naczelnego Sądu Administracyjnego z dnia 28 października 2016 r., sygn. akt I OSK 603/15, LEX nr 2168115.
} 
1) informacje o wysokości wynagrodzenia uzgodnionego z nadawcą przesyłki;

2) informacje o wynagrodzeniu płatnym podwykonawcy;

3) dane dotyczące nadawcy lub odbiorcy przesyłki;

4) dane dotyczące przewoźnika faktycznie realizującego przewóz.

Informacje o wynagrodzeniu ustalonym z nadawcą przesyłki mogą stanowić tajemnicę wobec podwykonawcy realizującego przewóz. Wydaje się oczywiste bowiem, że znaczna dysproporcja między wynagrodzeniem pośrednika a wynagrodzeniem zaoferowanym przewoźnikowi, w sytuacji ujawnienia tej informacji przewoźnikowi, mogłaby doprowadzić do prób renegocjacji wynagrodzenia przez tego ostatniego, a w przypadku braku osiągnięcia porozumienia - skutkować odmową wykonania umowy przez przewoźnika.

$\mathrm{Z}$ kolei informacja o stawce wynagrodzenia podwykonawcy (przewoźnika faktycznie realizującego przewóz) może stanowić tajemnicę przedsiębiorstwa szczególnie wobec nadawcy przesyłki z takiego względu, że nadawca, chcąc wyeliminować pośrednika, mógłby zlecać wykonywanie umów przewozu bezpośrednio przewoźnikowi. $Z$ tego samego względu dane dotyczące przewoźnika również mogą stanowić tajemnicę w stosunku do nadawcy przesyłki.

Jednak informacja o stawkach wynagrodzenia przewoźnika może stanowić również tajemnicę wobec innych przewoźników realizujących umowy na rzecz danego przedsiębiorcy. Dotyczy to szczególnie przedsiębiorców spedycyjnych, których działalność polega głównie na organizacji przewozu. W przypadku zawierania przez tego typu przedsiębiorców umów o świadczenie umów przewozowych nierzadko stawka wynagrodzenia ustalana jest za pokonanie jednego kilometra. Nietrudno sobie zatem wyobrazić sytuację, w której ujawnienie wynagrodzenia jednego przewoźnika innemu, realizującemu przewozy na podobnej trasie, może spowodować żądanie przewoźnika, który zgodził się wykonywać umowy za niższą stawkę kilometrową, podniesienie tej stawki, a w razie braku porozumienia - do rozwiązania umowy.

Jeżeli zaś chodzi o dane dotyczące nadawcy lub odbiorcy przesyłki, niekiedy bywa tak, że przedsiębiorcy przewozowi (konkretnie - przedsiębiorcy zajmujący się potocznie rozumianą spedycją), stale współpracujący z zakładami produkcyjnymi strzegą ich danych, aby uniknąc sytuacji, w której podwykonawcy będą oferować umowy przewozu bezpośrednio zakładom produkcyjnym, co doprowadziłoby do wyeliminowania pośrednictwa danej spedycji. Utajnieniu danych służyć może tzw. neutralizacja dokumentów przewozowych, a także zastrzeżenie kar umownych za podjęcie współpracy bezpośrednio z zakładem produkcyjnym, o którym przewoźnik powziął informację z umowy, którą realizował na rzecz pośrednika. O tych środkach ochrony tajemnicy przedsiębiorstwa przewozowego będzie mowa w następnej części rozważań. 


\section{2. ŚRODKI OCHRONY TAJEMNICY PRZEDSIĘBIORSTWA PRZEWOZOWEGO}

\subsection{NEUTRALIZACJA DOKUMENTÓW}

Jak wskazano wyżej, tzw. neutralizacja dokumentów przewozowych służy ochronie pośrednika organizującego przewóz przesyłki. Polega ona na utajnieniu danych faktycznego nadawcy lub odbiorcy wobec podwykonawcy realizującego przewóz. W praktyce odbywa się to w ten sposób, że pośrednik (spedytor) wpisuje w polu oznaczonym jako „odbiorca” albo „miejsce przeznaczenia” dane podmiotu zlecającego przewóz, tj. swoje dane. Podobnie, jeżeli utajnione wobec przewoźnika mają zostać dane ostatecznego odbiorcy, pośrednicy wpisują jedynie kraj miejsca przeznaczenia przesyłki wraz z kodem pocztowym.

Należy jednak w tym miejscu zaznaczyć, że praktyka polegająca na zobowiązaniu przewoźnika do dokonania neutralizacji dokumentów, choć powszechna, nie jest zgodna z prawem, jej stosowanie powoduje bowiem naruszenie art. 55a ust. 1 pkt Prawa przewozowego, zgodnie z którym zabrania się nadawcy umieszczania w liście przewozowym i innych dokumentach danych i informacji niezgodnych ze stanem faktycznym. Zgodnie z ust. 2 przywołanego przepisu, zakaz ten odnosi się również do spedytora, odbiorcy, organizatora transportu lub innego podmiotu zlecającego przewóz. Stąd też podmiot zlecający wykonanie umowy przewozu, tj. nadawca, nie może zasłaniać się zasadą swobody umów wyrażoną w art. 353 Kodeksu cywilnego ${ }^{14}$, bowiem przepis ten wprost stanowi, że swoboda umów ograniczona jest m.in. treścią ustawy, której umowa nie może naruszać.

\subsection{KARY UMOWNE I ROSZCZENIE ODSZKODOWAWCZE NA ZASADACH OGÓLNYCH}

Kolejnym środkiem ochrony szeroko rozumianej tajemnicy przedsiębiorstwa przewozowego są kary umowne zastrzegane w treści umów przewozu. Zgodnie z art. $483 \S 1$ k.c. kara umowna może być zastrzeżona wyłącznie za niewykonanie lub nienależyte wykonanie zobowiązania niepieniężnego. W zakresie ochrony tajemnicy przedsiębiorstwa przewozowego można przykładowo wymienić karę umowną za brak omawianej wyżej neutralizacji dokumentów czy, stosowną również powszechnie, karę za wejście w bezpośrednie relacje handlowe z podmiotem będącym załadowcą przesyłki.

\footnotetext{
${ }^{14}$ Ustawa z dnia 23 kwietnia 1964 r. - Kodeks cywilny,. Dz. U. z 2019 r., poz. 1145 [dalej cyt.: k.c.].
} 
Brak skuteczności zastrzeżenia pierwszej z wymienionych kar umownych nie powinien budzić zastrzeżeń, jako że tak określony obowiązek przewoźnika narusza powszechnie obowiązujące przepisy prawa. Skoro zatem swoboda umów ograniczona jest m.in. treścią ustawy, należy uznać, że kara umowna zastrzeżona na okoliczność naruszenia postanowień umowy sprzecznych z prawem nie zasługuje na ochronę prawną. Stanowisko to znajduje również aprobatę judykatury - w kwestii tej wypowiedział się m.in. Sąd Apelacyjny w Białymstoku, trafnie zauważając, że w świetle art. $353^{1}$ k.c. swoboda umów ograniczona jest właściwościami (naturą) stosunku prawnego, przepisami ustawy oraz zasadami współżycia społecznego. Strony zatem nie mogą w umowie tak rozszerzyć odpowiedzialności dłużnika z tytułu niewykonania lub nienależytego wykonania zobowiązania ani dotyczącej kary umownej, by jej zakres był sprzeczny z naturą odpowiedzialności dłużnika za niewykonanie zobowiązania oraz z naturą kary umownej ${ }^{15}$. Wprawdzie należy zauważyć, że sąd ten odnosił się przede wszystkim do niemożności dochodzenia roszczenia z kary umownej w przypadku zastrzeżenia jej na wypadek niewykonania lub nienależytego wykonania umowy na skutek okoliczności, za które odpowiedzialność ponosi wierzyciel, jednakże nie powinno ulegać wątpliwości, że niewykonanie zobowiązania polegającego na działaniu sprzecznym z powszechnie obowiązującymi przepisami prawa również stoi w sprzeczności z naturą odpowiedzialności dłużnika. Ponadto nie należy zapominać, że zgodnie z art. 38 Prawa przewozowego to nadawca przesyłki wystawia list przewozowy, zamieszczając w nim dane wymienione w ust. 2 tego artykułu, wobec czego nakładanie na przewoźnika kary umownej za brak wpisania określonych danych w liście przewozowym również oznaczałoby zastrzeżenie tej kary za niewykonanie czynności, które nie należą do przewoźnika.

Odnośnie do drugiej z wymienionych kar umownych, tj. stosowanych w razie podjęcia bezpośrednich kontaktów handlowych z podmiotem faktycznie wysyłającym przesyłkę, należy wskazać, że kara ta jest środkiem służącym ochronie interesów pośrednika. W interesie przedsiębiorcy spedycyjnego leży bowiem, aby przewoźnik dokonywał transakcji z nim, a nie - bezpośrednio z załadowcą. O ile zastrzeżenie kary umownej nie wydaje się w tym wypadku sprzeciwiać naturze stosunku prawnego ani tym bardziej naruszać przepisów ustawy, o tyle dochodzenie roszczenia na tej podstawie może stanowić pewien problem. Po pierwsze, należy uznać, że bezwzględny zakaz zawierania umów bezpośrednio z załadowcą przesyłki, bez żadnego ograniczenia czasowego, stanowi istotne naruszenie swobody działalności gospodarczej. Odmienne stanowisko prowadziłoby do sytuacji,

15 Wyrok Sądu Apelacyjnego w Białymstoku z dnia 16 kwietnia 2019 r., sygn. akt I ACa 802/18, LEX nr 2669471. 
w której jednorazowe podjęcie zlecenia od spedytora już zawsze uniemożliwiałoby zawarcie umowy z podmiotem faktycznie wysyłającym przesyłkę, co w znaczący sposób godziłoby $\mathrm{w}$ bezpieczeństwo i swobodę obrotu gospodarczego. $\mathrm{Z}$ tego względu przedsiębiorcy spedycyjni nierzadko stosują ograniczenie czasowe takiego zakazu, wskazując np. trzy-, cztero- czy sześciomiesięczny zakaz podejmowania zleceń bezpośrednio od załadowcy. W takiej sytuacji wykazanie naruszenia umowy przez przewoźnika jest stosunkowo łatwe, jednakże w dalszym ciągu dochodzenie roszczeń z tego tytułu może być skomplikowane. O ile wprawdzie uprawnienie do naliczenia kary umownej aktualizuje się poprzez samo naruszenie postanowień umownych, na co wskazuje art. $484 \S 1$ k.c., zgodnie z którym kara umowna należy się wierzycielowi w zastrzeżonej na ten wypadek wysokości bez względu na wysokość poniesionej szkody, o tyle pamiętać należy, że kara nie może stać w istotnej dysproporcji między stopniem naruszenia a poniesioną szkodą. Za nietrafne należy w tym miejscu uznać stanowisko Sądu Najwyższego, który w uchwale 7 sędziów o mocy zasady prawnej stwierdził, że zastrzeżenie kary umownej na wypadek niewykonania lub nienależytego wykonania zobowiązania nie zwalnia dłużnika z obowiązku jej zapłaty w razie wykazania, że wierzyciel nie poniósł szkody ${ }^{16}$. Literalne brzmienie art. $484 \S 1$ k.c. wskazuje na to, że kara umowna należy się wierzycielowi „bez względu na wysokość poniesionej szkody”. Zasadny jest wobec tego wniosek, że wierzyciel musi ponieść jakąkolwiek szkodę. Gdyby bowiem intencją prawodawcy, mając na względzie jego racjonalność, byłoby dopuszczenie naliczenia kary umownej w oderwaniu od tego, czy wierzyciel poniósł szkodę, czy też nie, przepis ten powinien być sformułowany inaczej, np. poprzez stwierdzenie, że „kara umowna należy się wierzycielowi w zastrzeżonej na ten wypadek wysokości bez względu na poniesienie szkody". Ponadto nie należy pomijać treści art. $483 \S 1$ k.c., zgodnie z którym można zastrzec w umowie, że naprawienie szkody wynikłej z niewykonania lub nienależytego wykonania zobowiązania niepieniężnego nastąpi przez zapłatę określonej sumy (kara umowna). Jeśli więc w przepisie tym mowa jest o naprawieniu szkody, nie ulega wątpliwości, że wierzyciel musi ponieść jakąkolwiek szkodę. Słuszne w tym zakresie jest również stanowisko sądów powszechnych, wyrażone m.in. przez Sąd Apelacyjny w Katowicach, który doszedł do wniosku, że kara umowna, podobnie jak odszkodowanie, którego jest surogatem, nie może prowadzić do nieuzasadnionego wzbogacenia uprawnionego, kosztem obowiązanego ${ }^{17}$.

${ }^{16}$ Uchwała Sądu Najwyższego 7 sędziów - zasada prawna z dnia 6 listopada 2003 r., sygn. akt III CZP 61/03, „Orzecznictwo Sądu Najwyższego Izba Cywilna” 2004, nr 6, poz. 1.

${ }^{17}$ Sąd Apelacyjny w Katowicach w wyroku z dnia 17 grudnia 2008 r., sygn. akt V ACa 483/08, LEX nr 491137. Podobnie również Sąd Okręgowy w Szczecinie w wyroku z dnia 24 czerwca 2016 r., sygn. akt VIII Ga 112/16, LEX nr 2091689. 
Przekładając powyższe rozważania na grunt omawianej problematyki należy zauważyć, że nie zawsze zastrzeżenie w ten sposób kary umownej będzie niedopuszczalne. Można bowiem sobie wyobrazić sytuację, w której przewoźnik zwróci się bezpośrednio do załadowcy, oferując wykonywanie przewozów z pominięciem przedsiębiorcy spedycyjnego po bardziej atrakcyjnych stawkach, w następstwie czego załadowca zmniejszy wolumen umów zawieranych z pośrednikiem lub też całkowicie zerwie z nim współpracę. Wówczas dochodzenie przez pośrednika kary umownej od przewoźnika byłoby zasadne, bowiem bez wątpienia poniósłby on szkodę. Gdyby z kolei przewoźnik wnosił o miarkowanie kary umownej $\mathrm{z}$ uwagi na jej rażące wygórowanie, zgodnie z art. 484 § 2 k.c., uprawniony do naliczenia kary umownej pośrednik powinien wykazać poniesienie szkody oraz jej zakres. W przypadku braku wskazanej przesłanki miarkowania kary umownej, tj. gdy wysokość kary umownej jest zbliżona do poniesionej szkody, należy uznać, że należałaby się ona pośrednikowi w pełnej kwocie nawet, jeżeli wystąpiłaby pewna dysproporcja miedzy jej wysokością a poniesioną szkodą. Należy bowiem pamiętać, że przesłanką miarkowania jest „rażące wygórowanie” kary umownej, co znajduje potwierdzenie w stanowisku doktryny, zgodnie z którym nie jest wystarczający jakiś stopień wygórowania kary umownej, ale jedynie bardzo duże (rażące) wygórowanie, przy czym jako kryterium miarkowania wskazuje się stosunek wysokości kary umownej do wysokości odszkodowania na zasadach ogólnych, co pozwala uwzględnić m.in. szkodę, przyczynienie się wierzyciela, stopień winy obu stron, zmianę cen, trudności dowodowe, niski stopień winy dłużnika, stosunek kary do szkody poniesionej przez wierzyciela, ogół interesów majątkowych i niemajątkowych lub ogół kryterium, ponieważ miarkowanie należy do tzw. prawa sędziowskiego ${ }^{18}$. Należy jednak zwrócić uwagę, że wykazanie, że kara umowna nie jest rażąco wygórowana, będzie leżało w takim przypadku po stronie wierzyciela.

Niekiedy, w szczególności w przypadku braku zastrzeżenia stosownej kary umownej w umowie przewozu, poszkodowanemu podmiotowi nie pozostaje inna droga, jak tylko dochodzenie roszczenia odszkodowawczego na zasadach ogólnych. Wówczas podmiot ten musi wykazać nie tylko fakt poniesienia szkody, ale również normalny związek przyczynowo-skutkowy między działaniem osoby naruszającej tajemnicę przedsiębiorstwa a szkodą, a także jej wysokość. Może to rodzić pewne problemy, szczególnie w zakresie określenia wysokości poniesionej szkody. O ile bowiem w przypadku opisywanym powyżej, tj. nawiązaniu bezpośredniej współpracy między przewoźnikiem a załadowcą z pominięciem pośrednika, fakt

${ }^{18}$ P. ZaKrzewski, Komentarz do art. ..., [w:] Kodeks cywilny. Komentarz. Tom III. Zobowiazania. Część ogólna (art. 353-534), red. M. Fras, M. Habdas, LEX/el. 2019. 
wystąpienia szkody oraz związek przyczynowo-skutkowy wydaje się być wyraźny, o tyle sama wysokość szkody nie jest sprawą oczywistą. Zwykle to koniunktura rynkowa dyktuje liczbę przewożonych ładunków oraz wysokość wynagrodzenia pośrednika. Nie jest zatem powiedziane, że jeżeli przez jakiś okres pośrednik organizował pewną liczbę ładunków na rzecz załadowcy i otrzymał za to określone wynagrodzenie, to przez analogiczny okres w przyszłości liczby te utrzymałyby się na podobnym poziomie. Mogłyby one wzrosnąć, ale również przeciwnie - liczba zawieranych umów (przy założeniu braku istnienia ramowej umowy o współpracy, określającej minimalną liczbę ładunków w danym okresie) mogłaby zmaleć w sposób naturalny, tj. poprzez brak odpowiednich potrzeb rynkowych. W praktyce często stosuje się rozwiązanie polegające na uśrednieniu liczby zawieranych zleceń oraz otrzymywanego za nie wynagrodzenia w danym czasie i ustalenie wysokości odszkodowania w ten sposób. Inną metodą jest oznaczenie wysokości szkody na podstawie liczby ładunków przewożonych przez przewoźnika na bezpośrednie zlecenie załadowcy, jednakże $\mathrm{w}$ takim wypadku jest to o tyle utrudnione, że pośrednik często nie ma dostępu do tych danych, a w interesie przewoźnika z całą pewnością nie jest przekazywanie ich dotychczasowemu zleceniodawcy. Nie należy również zapominać, że dane te stanowią element tajemnicy przedsiębiorstwa tego przewoźnika, wobec czego ich pozyskanie przez pośrednika również wiązałoby się z naruszeniem tej tajemnicy. Z kolei trudno oczekiwać, że na etapie procesu sąd miałby zobowiązywać przewoźnika do wskazania tych danych, bowiem obowiązkiem powoda jest oznaczenie wartości przedmiotu sporu w pozwie. Stąd też bardziej miarodajną metodą wydaje się szacowanie rozmiarów poniesionej szkody w ramach negatywnego interesu umownego przez powoda, którą to szkodę będzie weryfikował sąd na etapie postępowania.

\subsection{ZAKAZ KONKURENCJI}

Ochrona tajemnicy przedsiębiorstwa przewozowego znajduje często wyraz w umowach o zakazie konkurencji zawieranych z pracownikami czy podwykonawcami działającymi na rzecz przedsiębiorcy w ramach prowadzonej przez siebie działalności gospodarczej. Jest to zrozumiałe, bowiem pracownicy odpowiadający za organizację umów przewozu posiadają informacje o kierunkach przewożonych towarów, ich rentowności (często zdarza się tak, że transporty realizowane z czy do określonych miejsc są lepiej płatne niż inne), stosowanych stawek, czy przede wszystkim - klientów oraz przewoźników wykonujących umowy na rzecz przedsiębiorcy. Nierzadko zdarza się tak, że odejście z pracy danego pracownika pociąga za sobą rozwiązanie współpracy z danym klientem czy przewoźnikiem, który niejako „idzie za pracownikiem”. Wobec tego, dla ochrony swoich inte- 
resów, przedsiębiorcy decydują się niekiedy na zawieranie z pracownikami czy spedytorami kontraktowymi umów o zakazie konkurencji zarówno w trakcie, jak i po ustaniu współpracy.

Skuteczne zawarcie takiej umowy uzależnione jest od spełnienia przesłanek wskazanych w Rozdziale IIa Działu czwartego Kodeksu pracy ${ }^{19}$. W pierwszej kolejności musi zostać spełniony wymóg formalny, tj. pisemna forma umowy o zakazie konkurencji, przewidziana art. $101^{3}$ k.p., zastrzeżona z rygorem nieważności. Po drugie, ustawodawca zaznaczył, że zawarcie umowy o zakazie prowadzenia przez pracownika działalności konkurencyjnej, wymaga „odrębnej umowy”. W doktrynie wskazuje się na dwa zasadnicze poglądy dotyczące tego pojęcia - z jednej strony kładzie się nacisk na literalne brzmienie tego przepisu, a z drugiej - wskazuje, że zwrot „odrębna umowa” nie może być rozumiany literalnie (dosłownie), ale oznacza wyłącznie, że strony muszą odrębnie umówić się co do zakazu konkurencji ${ }^{20}$. Wydaje się, że na większą aprobatę zasługuje drugi pogląd, a klauzula zakazu konkurencji, stanowiąca element umowy o pracę, będzie interpretowana jako odrębna umowa przy założeniu, rzecz jasna, że będzie wskazywać na zakres działań konkurencyjnych, od których powinien powstrzymać się pracownik. Wypada również zwrócić uwagę na wyrok Sądu Najwyższego, który stwierdził, że „dokumentowi o nazwie «zakres obowiązków, odpowiedzialności i uprawnień» nie można przypisać charakteru umowy o zakazie konkurencji w rozumieniu art. $101^{1}$ k.p. Zakres obowiązków pracowniczych może bowiem jedynie konkretyzować te obowiązki. Natomiast przepis art. $101^{1} \S 1$ k.p. stanowi o zawarciu odrębnej umowy o zakazie konkurencji”"21. Wydawać się może, że Sąd Najwyższy stanął na stanowisku hołdującym literalnej wykładni przepisu art. $101^{1}$ k.p., jednakże z uzasadnienia tego wyroku wynika, że ,zakres zakazanych działań konkurencyjnych powinien być skonkretyzowany w umowie o zakazie konkurencji, a strony nie ustaliły zakresu przedmiotowego, podmiotowego, terytorialnego ani czasowego (czy umowa ma obowiązywać w trakcie, czy po zakończeniu stosunku pracy) obowiązywania wskazanego zapisu. Dlatego też sąd odmówił powyższym zapisom waloru umowy o zakazie konkurencji”22. Oznacza to, że samo ujęcie klauzuli o zakazie konkurencji $\mathrm{w}$ innym dokumencie nie przesądzało jeszcze o nieskuteczności ustanowienia tego zakazu, a inne uchybienia nie pozwoliły na uznanie powyższych postanowień za wiążące, co koresponduje ze stanowiskiem doktryny wyrażonym powyżej.

${ }^{19}$ Ustawa z dnia 26 czerwca 1974 r. - Kodeks pracy, Dz. U. z 2019 r., poz. 1040 z późn. zm. [dalej cyt.: k.p.].

${ }^{20}$ P. PrusinowsKi, Komentarz do art. 1013, [w:] Kodeks pracy. Komentarz, red. K. Baran, LEX/ el. 2019.

${ }^{21}$ Wyrok Sądu Najwyższego z dnia 20 sierpnia 2009 r., sygn. akt II PK 41/09, LEX nr 590319.

22 Tamże. 
Kolejnym elementem konstrukcyjnym umowy o zakazie konkurencji jest jej zakres. Wlicza się w to formy działalności konkurencyjnej, ale także np. zakres terytorialny. Niewątpliwie jednym z najistotniejszych elementów umowy o zakazie konkurencji po ustaniu stosunku pracy jest czas trwania zakazu. Ustawodawca wprost wskazał obowiązek zastrzeżenia tego okresu - brak stosownego zastrzeżenia w tym zakresie skutkować będzie nieważnością umowy, zgodnie ze stanowiskiem m.in. Sądu Najwyższego, który stwierdził, że nie dochodzi do ustanowienia zakazu działalności konkurencyjnej po ustaniu stosunku pracy w razie pominięcia w umowie postanowienia określającego czas trwania tego zakazu ${ }^{23}$.

Również ważnym elementem umowy o zakazie prowadzenia działalności konkurencyjnej po ustaniu stosunku pracy jest odszkodowanie należne byłemu pracownikowi. Zgodnie z art. $101^{2} \S 3$ k.p. nie może być ono niższe niż $25 \%$ wynagrodzenia otrzymanego przez pracownika przed ustaniem stosunku pracy przez okres odpowiadający okresowi obowiązywania zakazu konkurencji. Brak określenia wysokości odszkodowania, zastrzeżenie wprost, że zakaz konkurencji jest bezpłatny albo zastrzeżenie odszkodowania w wysokości niższej niż przewidziana przepisami nie powoduje, jak się wskazuje w orzecznictwie, nieważności całej umowy, ale wywołuje ten skutek, że w miejsce postanowień mniej korzystnych niż zawarte w art. $101^{2} \S 3$ k.p., zastosowanie znajdzie ten przepis ${ }^{24}$. Należy jednak podkreślić, że ograniczenie w zakresie wysokości odszkodowania dotyczą wyłącznie pracowników - w przypadku spedytorów kontraktowych, będących przedsiębiorcami, prowadzącymi jednoosobową działalność gospodarczą, ograniczenie to nie obowiązuje, a strony mogą dowolnie skonstruować stosunek prawny w tym zakresie. Ewentualne zarzuty zobowiązanego do powstrzymania się od działalności konkurencyjnej (np. zbyt niskie odszkodowanie oraz nierówność stron umowy) mogą być rozpatrywane przez pryzmat klauzul generalnych, takich jak np. zasady współżycia społecznego, na zasadach ogólnych, jednakże kwestia ta może być w pewnym stopniu utrudniona $\mathrm{z}$ uwagi na zawarcie umowy w obrocie dwustronnie profesjonalnym.

Kolejnym elementem stanowiącym zabezpieczenie interesów przedsiębiorcy w przypadku umowy o zakazie prowadzenia działalności konkurencyjnej po ustaniu stosunku pracy jest zastrzeżenie kary umownej na okoliczność złamania tego zakazu przez byłego pracownika. Oczywiście kara ta nie może być rażąco wygórowana w stosunku do zastrzeżonego na rzecz pracownika odszkodowania, bowiem pod-

${ }^{23}$ Wyrok Sądu Najwyższego z dnia 2 października 2003 r., sygn. akt. I PK 453/02, „Orzecznictwo Sądu Najwyższego Izba Pracy, Ubezpieczeń Społecznych i Spraw Publicznych” 2004, nr 19, poz. 331

${ }^{24}$ Zob. m.in. wyroki Sądu Najwyższego z dnia 17 grudnia 2001 r., sygn. akt I PKN 742/00, LEX nr 50474 oraz z dnia 3 grudnia 2003 r., sygn. akt III PZP 16/03, LEX nr 82139. 
lega ona miarkowaniu na zasadach ogólnych wskazanych w art. 484 §2 k.c. Stąd też przyjętą praktyką jest zastrzeganie kar umownych w kwocie odpowiadającej wynagrodzeniu zastrzeżonego na rzecz pracownika, a także formułowanie klauzul przewidujących obowiązek zwrotu otrzymanego odszkodowania po naruszeniu przez pracownika zakazu konkurencji.

\section{WNIOSKI}

Tajemnica przedsiębiorstwa w przypadku przedsiębiorcy prowadzącego działalność gospodarczą w zakresie przewozu drogowego towarów może przyjmować postać różnorodnych informacji. Ich katalog jest więc niewątpliwie otwarty, istotne jest natomiast, aby informacje te prezentowały wartość gospodarczą z punktu widzenia podmiotu zajmującego się tą dziedziną. Można w tym zakresie przede wszystkim wskazać informacje o trasach, stawkach czy tzw. bazę klientów.

Prawo cywilne oferuje pewien wachlarz środków ochrony tajemnicy przedsiębiorstwa przewozowego, a ponadto dodatkowe możliwości stwarza praktyka obrotu gospodarczego. Do najpopularniejszych środków ochrony zaliczyć należy kary umowne, które mają, z jednej strony, charakter odszkodowawczy i w tym zakresie ich celem jest naprawienie szkody poniesionej przez przedsiębiorcę na skutek naruszenia poufności pewnych informacji, a z drugiej - charakter represyjny i prewencyjny. W tym zakresie ochrona podejmowana jest w sposób wyprzedzający, bowiem wizja naliczenia kary umownej przez wierzyciela może i niekiedy skutkuje powstrzymaniem się od czynności mogących stanowić naruszenie tajemnicy przedsiębiorstwa.

Kary umowne mogą współistnieć z innymi środkami ochrony, stanowiąc rzeczywistą sankcję za niewywiązanie się przez osobę zobowiązaną z zaciągniętych zobowiązań. W szczególności mogą one zostać zastrzeżone za naruszenie umowy o zakazie konkurencji po ustaniu stosunku pracy, ale także za nawiązanie bezpośrednich relacji handlowych z podmiotem wysyłającym przesyłkę, z pominięciem pośrednika. Wątpliwa jest natomiast możliwość naliczenia kary umownej za brak tzw. neutralizacji dokumentów przewozowych, będącej środkiem ochrony interesów pośrednika organizującego transport, wypracowanym przez praktykę obrotu. Wynika to $\mathrm{z}$ faktu, iż sama neutralizacja narusza powszechnie obowiązujące przepisy prawa, a nadto wystawienie listu przewozowego jest jednym z obowiązków ciążących na nadawcy przesyłki. Stąd też naliczanie kar umownych za niewykonanie postanowień umownych, zakładających naruszenie przepisów ustawy, a jednocześnie - za okoliczności obciążające nadawcę, należy uznać za niedopuszczalne. 
Ponadto przepisy prawa cywilnego dają możliwość formułowania roszczeń odszkodowawczych na zasadach ogólnych. Tutaj należy jednak pamiętać o konieczności wykazania faktu poniesienia szkody, precyzyjnego określenia jej rozmiarów oraz istnienia związku przyczynowo-skutkowego między naruszeniem tajemnicy przedsiębiorstwa a szkodą powstałą po stronie przedsiębiorcy. $\mathrm{Z}$ tego tytułu zastrzeżenie kary umownej wydaje się bardziej atrakcyjnym rozwiązaniem z perspektywy wierzyciela.

Branża przewozowa podlega jednak stałym przeobrażeniom, w szczególności w zakresie możliwości wykorzystania w niej nowych technologii, co rodzi konieczność przewidywania nowych sposobów ochrony tajemnicy przedsiębiorstwa przed potencjalnymi naruszeniami, zarówno $\mathrm{z}$ technicznego, jak i prawnego punktu widzenia. Powyższy katalog środków cywilnoprawnej ochrony tajemnicy przedsiębiorstwa przewozowego daje możliwość szerokiego ich zastosowania, niemniej w pewnej perspektywie czasowej wydaje się, że konieczne będzie sformułowanie przepisów, przewidujących dla przedsiębiorcy nowe środki ochrony prawnej, a stosowane dotychczas metody będą mogły stanowić ich uzupełnienie.

\section{BIBLIOGRAFIA}

\section{ŹRÓDŁA PRAWA}

Ustawa z dnia 23 kwietnia 1964 r. - Kodeks cywilny,. Dz. U. z 2019 r., poz. 1145.

Ustawa z dnia 26 czerwca 1974 r. - Kodeks pracy, Dz. U. z 2019 r., poz. 1040 z późn. zm.

Ustawa z dnia 15 listopada 1984 r. - Prawo przewozowe, Dz. U. z 2017 r., poz. 1983 z późn. zm.

Ustawa z dnia 16 kwietnia 1993 r. o zwalczaniu nieuczciwej konkurencji, Dz. U. z 2019 r., poz. 1010. Ustawa z dnia 6 września 2001 r. o transporcie drogowym, Dz. U. z 2019 r., poz. 58 z późn. zm. Ustawa z dnia 6 września 2001 r. o dostępie do informacji publicznej, Dz. U. z 2019 r., poz. 1429.

\section{ORZECZNICTWO}

Uchwała Sądu Najwyższego 7 sędziów - zasada prawna z dnia 6 listopada 2003 r., sygn. akt III CZP 61/03, „Orzecznictwo Sądu Najwyższego Izba Cywilna” 2004, nr 6, poz. 1.

Wyrok Sądu Najwyższego z dnia 3 października 2000 r., sygn. akt I CKN 304/00, „Orzecznictwo

Sądu Najwyższego Izba Cywilna” 2001, nr 4, poz. 59.

Wyrok Sądu Najwyższego z dnia 17 grudnia 2001 r., sygn. akt I PKN 742/00, LEX nr 50474.

Wyrok Sądu Najwyższego z dnia 2 października 2003 r., sygn. akt. I PK 453/02, „Orzecznictwo Sądu

Najwyższego Izba Pracy, Ubezpieczeń Społecznych i Spraw Publicznych” 2004, nr 19, poz. 331. Wyrok Sądu Najwyższego z dnia 3 grudnia 2003 r., sygn. akt III PZP 16/03, LEX nr 82139. Wyrok Sądu Najwyższego z dnia 20 sierpnia 2009 r., sygn. akt II PK 41/09, LEX nr 590319.

Wyrok Naczelnego Sądu Administracyjnego z dnia 28 października 2016 r., sygn. akt I OSK 603/15, LEX nr 2168115.

Wyrok Sądu Apelacyjnego w Katowicach z dnia 17 grudnia 2008 r., sygn. akt V ACa 483/08, LEX nr 491137. 
Wyrok Sądu Apelacyjnego w Białymstoku z dnia 16 kwietnia 2019 r., sygn. akt I ACa 802/18, LEX nr 2669471.

Wyrok Sądu Okręgowego w Szczecinie z dnia 24 czerwca 2016 r., sygn. akt VIII Ga 112/16, LEX nr 2091689.

\section{LITERATURA}

Bogdalski Piotr: Tajemnica przedsiębiorstwa - zagadnienia konstrukcyjne, Monitor Prawniczy 6 (1997), s. 228-233.

Kodeks cywilny. Komentarz. Tom III. Zobowiązania. Część ogólna (art. 353-534), red. M. Fras, M. Habdas, LEX/el. 2019.

Kodeks pracy. Komentarz, red. K. Baran, LEX/el. 2019.

NowiŃsKa Ewa, Szczepanowska-KozŁowska Krystyna: Ustawa o zwalczaniu nieuczciwej konkurencji. Komentarz, LEX/el. 2017.

System Prawa Własności Intelektualnej, t. III: Prawo wynalazcze, red. J. Szwaja, A. Szajkowski, Wrocław: Wydawnictwo Ossolineum 1990.

Ustawa o zwalczaniu nieuczciwej konkurencji. Komentarz, red. J. Szwaja, Warszawa: Wydawnictwo C.H. Beck 2016.

\section{INNE ŹRÓDŁA}

Informacje sygnalne GUS z dnia 14 czerwca 2019 r., [w:] https://stat.gov.pl/download/gfx/portalinformacyjny/pl/defaultaktualnosci/5511/11/7/1/przewozy_ladunkow_i_pasazerow_w_2018_roku. pdf [dostęp: 18.07.2019].

\section{CYWILNOPRAWNY MODEL OCHRONY TAJEMNICY PRZEDSIĘBIORSTWA PRZEWOZOWEGO}

\section{Streszczenie}

W ostatnim czasie dla przedsiębiorców atrakcyjne stało się zakładanie i prowadzenie działalności w zakresie przewozu drogowego i spedycji. Jak w wielu branżach, tak i w tej kluczowe znaczenie z punktu widzenia długofalowej rentowności przedsięwzięcia ma informacja. W tym zakresie można przykładowo wymienić tzw. bazę klientów, informacje o przewoźnikach, trasach czy stawkach wynagrodzenia. Z uwagi na gospodarczą przydatność tych informacji, ich poufny charakter, a także fakt, że przedsiębiorcy podejmują środki służące zapobieganiu ich upublicznienia, nie powinno ulegać wątpliwości, że noszą one cechy tajemnicy przedsiębiorstwa. Celem niniejszego opracowania jest omówienie najpowszechniejszych metod ochrony informacji stanowiących tajemnicę przedsiębiorstwa. Dotyczy to zarówno metod znajdujących szerokie zastosowanie w działalności gospodarczej (np. kary umowne), jak i tych szczególnych, uwzględniających specyfikę branży przewozowej (tzw. neutralizacja dokumentów). Jak się bowiem okazuje, w praktyce nie wszystkie metody tej ochrony są zgodne z przepisami, wobec czego nie wszystkie roszczenia przedsiębiorcy będą zasługiwać na ochronę prawną.

Słowa kluczowe: spedycja; przewóz; kary umowne; neutralizacja dokumentów; zakaz konkurencji; tajemnica przedsiębiorstwa 


\title{
CIVIL LAW MODEL FOR PROTECTION OF BUSINESS SECRET OF A TRANSPORT COMPANY
}

\begin{abstract}
Sum mary
Recently, the establishment and operation of road transport and forwarding has become attractive for entrepreneurs. As in many industries, information is of key importance for the long-term viability of the enterprise. In this regard, for example, the so-called customer base, information about carriers, routes or rates of remuneration. Due to the economic usefulness of this information, its confidential nature, and the fact that entrepreneurs take measures to prevent its disclosure, there should be no doubt that they bear the characteristics of business secrets. The purpose of this study is to discuss the most common methods of protecting business secret information. This applies to both methods that are widely used in business operations (e.g. contractual penalties), as well as those specific to the specificity of the transport industry (so-called document neutralization). As it turns out, in practice, not all methods of this protection are in accordance with the regulations, so not all claims of the entrepreneur will deserve legal protection.
\end{abstract}

Key words: forwarding; transport; contractual penalties; document neutralization; non-competition clause; trade secret 